de.

TRANS · núm. $21 \cdot 2017$

DOSIER · 63-74

Don Quixote: Two
Samples y un epitafio

Ilan Stavans 
In one way or another, Don Quixote has occupied my life for the last twenty years. Aside from teaching it-shall I say "religiously" - on a yearly basis, a regularity inspired by Faulkner, among other endeavors I have written a cultural biography of it (Quixote: The Novel and the World [Norton, 2015]), translated it in its entirety into Spanglish, and I am in the process of adapting it, with Venezuelan illustrator Roberto Weil, into graphic novel (in Spanish, English, and Spanish). Along the way I have engaged in conversation with a number of scholars (such as Diana de Armas Wilson ["Translating Don Quixote: A Conversation"] and William P. Childers ["Twitting the Windmills: Don Quixote in the Twenty-First Century"]) on the reach and versatility of Cervantes's masterpiece in today's world.

To me this devotion, maybe even obsession, is a source of constant renewal. The classics are lifelong companions and two of them from the Spanish-speaking world, Don Quixote and One Hundred Years of Solitude, published almost exactly 350 years apart, one in the matrix, the other in a former colony, have become not only objects of adoration but also fountain of sustenance.

What follows are two samples, chosen at random: the first is my collaboration with Weil, in its Spanglish avatar, of Part I, chapter

8, depicting the knight's battles with the windmills; the second is chapter 39 , which is part of "The Captive's Tale," also in Spanglish.

Rather than rehearse again the overall argument behind my translation, let me summarize it in three modes: Spanglish is the new mestizo tongue of a significant portion of the millions of Latinos in the United States; it is currently in a state of transition from the oral to the written plain; and there is no one variety of Spanglish but many and a standardized type is quickly gaining momentum. As I have said elsewhere, translation is synonymous with appropriation. By the way, Don Quixote isn't the only classic I have rendered into Spanglish; others include Shakespeare's Hamlet and Saint Exúpery's The Little Prince. Likewise, my adaptation of Cervantes' masterpiece into a graphic novel is ignited by a similar impetus: to bring it to a community of readers prone to other types of entertainment.

Is all this a Quixotic quest? No doubt. That, precisely, makes it palatable. Scholarship, for me, is an act of rebellion. To be worth, it ought to reach the general public. And it must show a creative edge. My epitaph, let me request it now, should be: Morir sane y vivir crazy.

-I.S., Wellfleet, Mass., April I5, 2017 


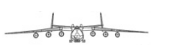

\section{DON QUIXOTE DE LA MANCHA}

Adaptado al Spanglish por Ilan Stavans

Ilustrated por Roberto Weil 
$\frac{1}{6010}$

66

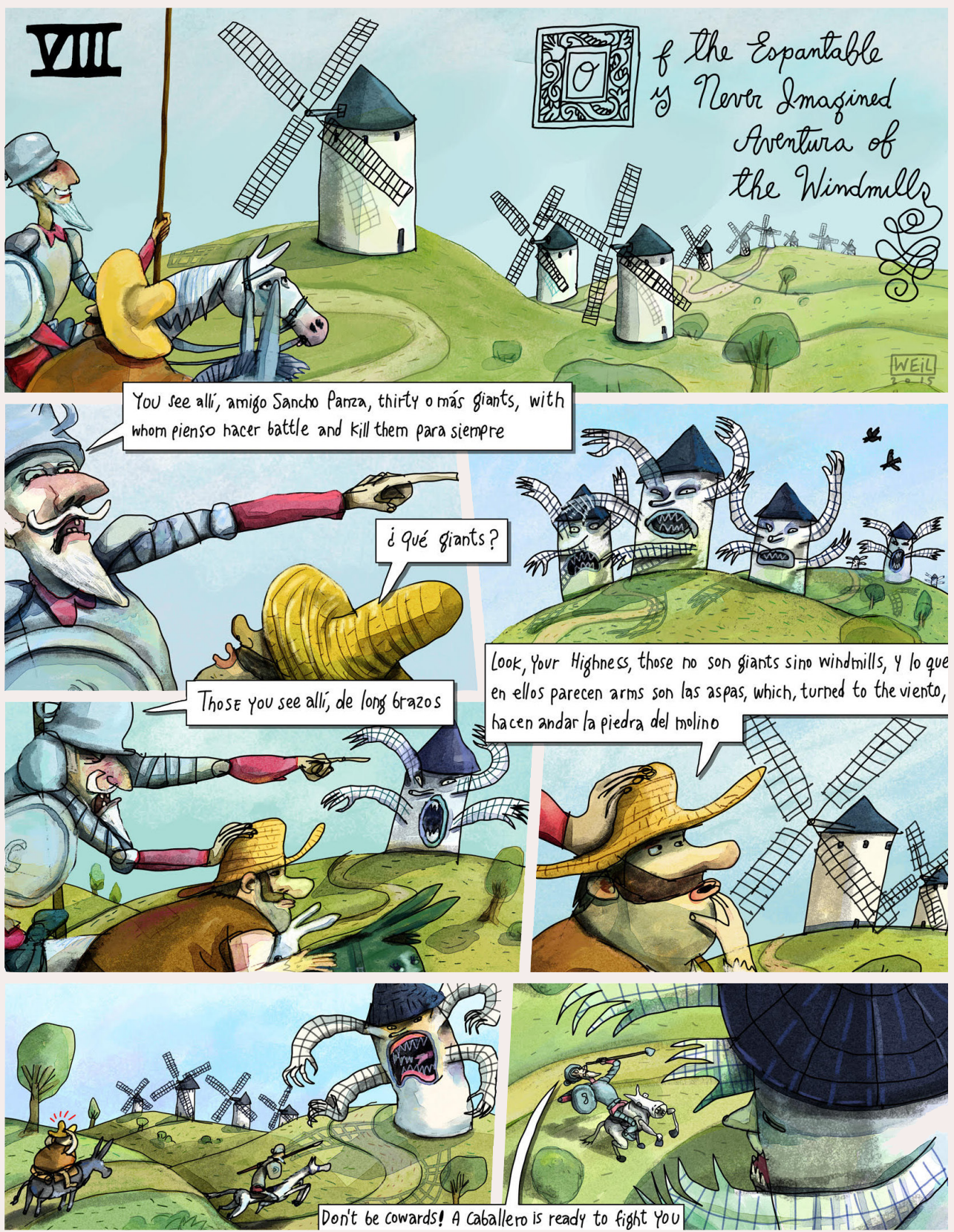



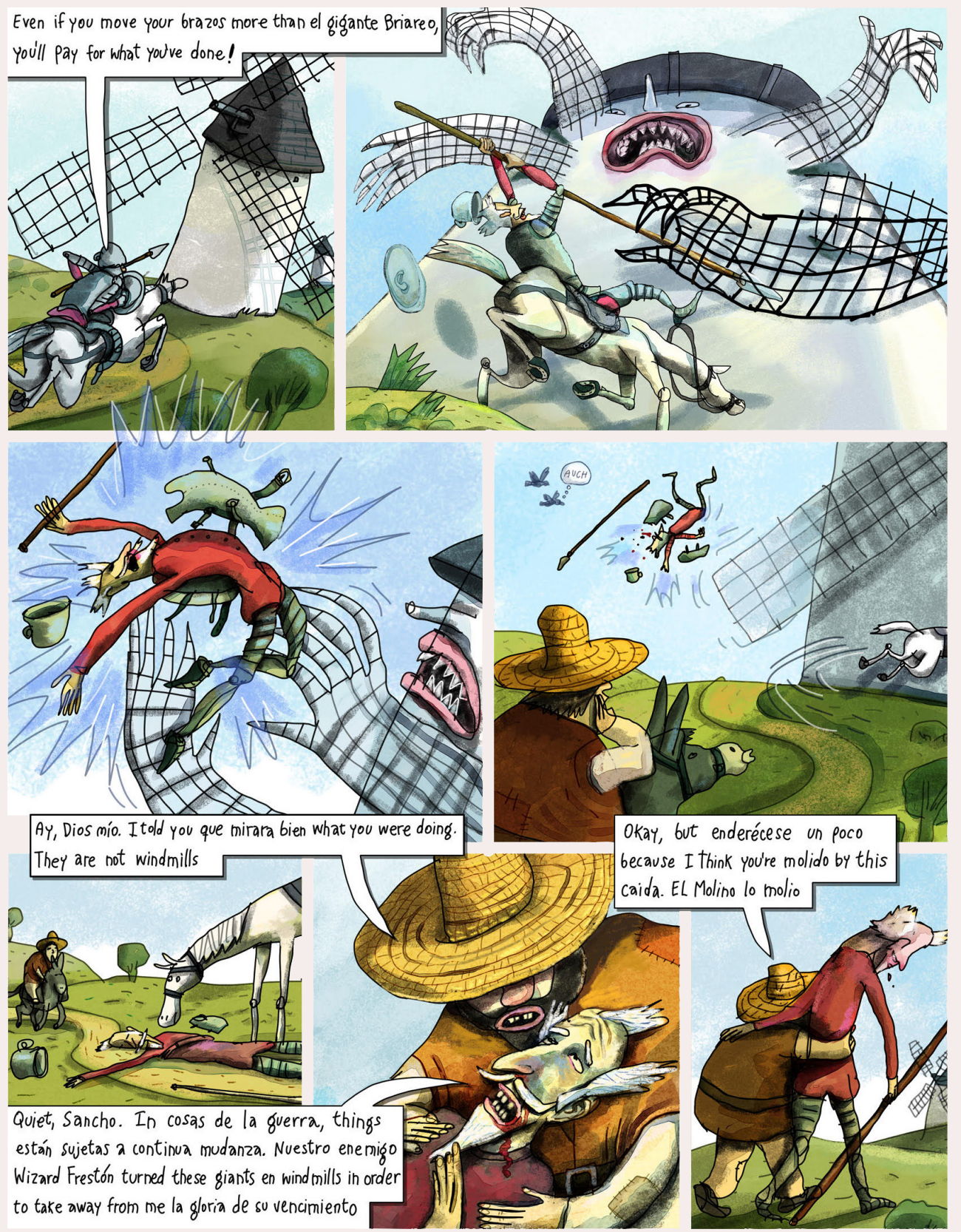
$\frac{1}{6 x}$

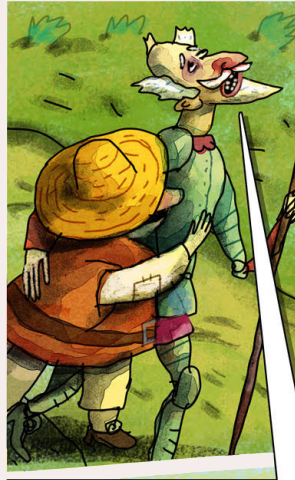

Asi es la verdad. And if I don't complain es porque it is not given a los caballeros andantes to quejarse for injuries, even if they lose their tripas
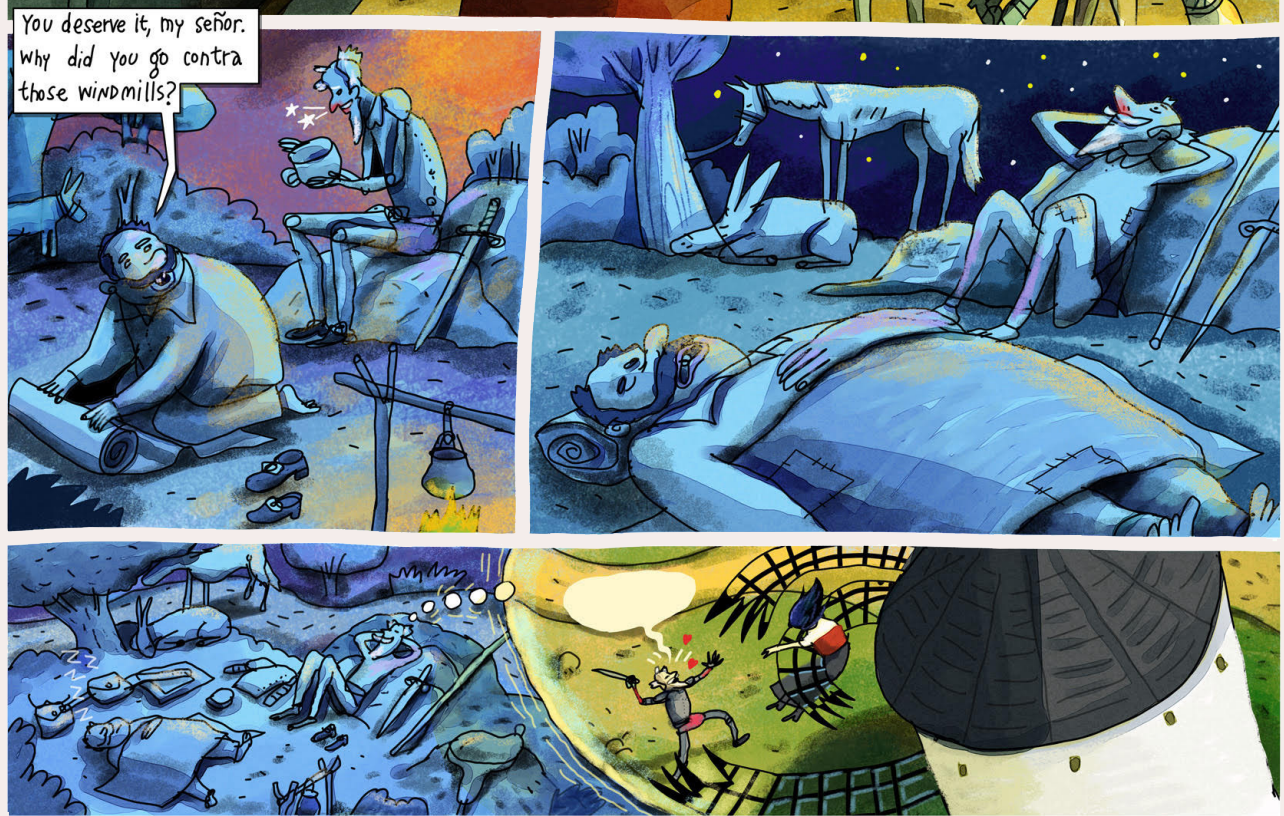


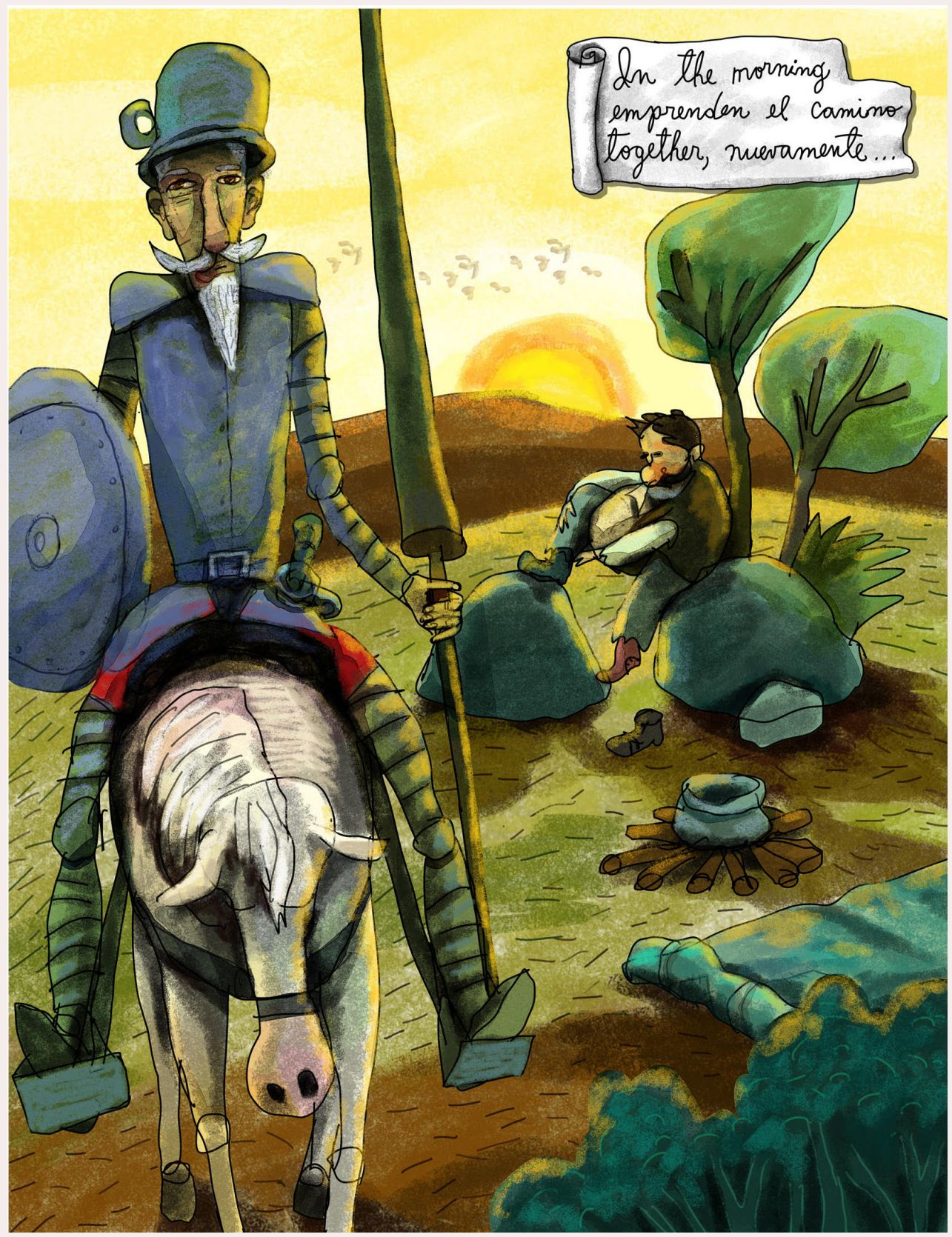

$\frac{1}{601000}$ 


\section{FIRST PARTE, CAPÍTULO THIRTY-NINE}

\section{Where el Cautivo Tells Su Vida and Sucesos}

My linaje had its origin en un lugar en las $\mathrm{Mou}-$ ntains de León, y la naturaleza had been kinder y más generosa to it than la fortuna, and though la pobreza general of those communities mi padre passed a ser un hombre rico; and he would have been so en la realidad had he diera maña in preserving his property como se la daba en gastarla. This tendency of his to be liberal y gastador la había obtenido from having been un soldado en su youth, for the soldier's life es una escuela donde el mesquino se hace freehanded and the free-handed pródigo; and if any soldiers se hallan miserables, they are monsters, lo que se ve raras times. Mi padre went beyond liberalidad y rayaba en prodigality, cosa by no means advantageous al hombre casado who has hijos to succeed to his nombre y posición. Mi padre had tres, all varones, and all de edad to make elección de profession. Viendo, then, that he no podía ir contra su condition, he resolved to divest himself del instrumento y cause of his prodigality y dadivosidad, to privarse himself of wealth, without which Alejandro himself would have seemed estrecho.

And so calling los tres aside un día into a room, nos dijo in words somewhat a las que ahora diré: «Hijos, to assure you that los quiero bien, no more is needed be known or said than que ustedes son mis hijos; and to encourage a suspicion that yo no los quiero, no more is needed than el conocimiento that I have no self-control as far as la preservación of your patrimonio is concerned; therefore, that you may for el futuro feel sure that yo los quiero como padre, and have no wish to aruinarlos like a padrastro, I propose to do con ustedes what I have for some time back meditado, and after deliberación madura decided upon. Ustedes son ahora de una edad to choose your line de vida or at least tomar decisiones of a calling que les traerán honor and profit cuando sean older; and what yo he decidido to do es dividir my property en cuatro partes; tres I will give to you, a cada uno su porción without making any difference, and la otra I will retain para vivir en ella and support myself por lo que queda of the life que el Cielo may be pleased to darme. But I wish que cada uno of you on taking possession of the share that cae en él to follow uno de los caminos I shall indicar. En esta España nuestra there is a proverbio, en mi opinión very true-como son todos, being short aphorisms drawn de la larga experiencia práctica-and al que me refiero dice, 'La Iglesia, o el mar, or the king's house;' as much as to say, en lengua sencilla, whoever wants to flourish y hacerse rico, let him follow la Church, or go al mar, adoptando el commercio como his calling, or estar al servicio del king en su casa, for se dice, 'Más vale migaja de rey que merced de señor.' Yo así digo because it is my voluntad and placer que uno de ustedes should follow las letras, another la mercancía, and the third sirva al rey y en la guerra, pues es un difficult matter to gain admission to his service en su casa real, y si la guerra does not bring mucha riqueza it confers mucho valor and mucha fama. Dentro de ocho días I will give you your full shares del dinero, without defraudarlos of a farthing, como verán in the end. Ahora díganme if you are willing to seguir my idea and consejo as I have propuesto before you.»

Mandándome a mí as the eldest to answer, yo, after urging him que no se deshiciese of his property sino que he should spend it all como fuera su voluntad, for nosotros were young men capaces to gain our sustento, aceptamos to comply with his deseos, and así mi destino was to follow la profesión de las armas and thereby serve a Dios y my king. Mi segundo hermano, 
having made la misma propuesta, decidió irse a las Indies, invirtiendo la porción that fell to him en mercancía. El más joven, and in mi opinión el más sabio, said que él major seguría el camino de la Church, or else, go a completar sus estudios en Salamanca. Tan pronto llegamos todos to an understanding, y optamos por nuestras profesiones, mi padre embraced us all, and en un poco tiempo he hizo todo lo que he had promised. And cuando él nos había dado to each su parte, which as well as yo recuerdo was tres mil ducados apiece en cash (porque un tío of ours compró la propiedad and paid for it down, para que no dejara de estar en la familia), los tres on the same day nos despedimos of our buen padre; and al mismo tiempo, as it seemed to me inhumano irme de mi padre with such scanty means en su vejez, lo persuadí to take dos of mis tres mil ducados, as lo sobrante would be enough to provide me con lo que necesitaría como soldado. Mis dos hermanos, moved by my ejemplo, le dieron cada uno each mil ducados, so that there was left for my father cuatro mil ducados in money, además de tres mil, el valor of la porción that fell to him which él prefirió retener in land instead of venderla. Finalmente, como dije, nos fuimos de donde vivíamos, y de nuestro tío whom I have mentioned, no sin tristeza and lágrimas on both sides, ellos nos pidieron to let them saber whenever an oportunidad offered cómo estábamos, whether bien o mal. Prometimos to do so, and cuando mi padre had abrazarnos and nos había dado his blessing, uno se fue a Salamanca, otro a Sevilla, and yo para Alicante, where I had oído that there was a vessel genovés taking in un cargo of lana para Génova.

It is now some ventidós años since me fui de mi padre's house, and todo este tiempo, aunque I have escrito several cartas, no he tenido noticias whatever de él or of mis hermanos. Ahora voy a contar briefly my own adventura during tal período. Me embarqué en Alicante, llegué a Génova after a prosperous viaje, and proceeded entonces to Milán, donde I provided myself 71 with armas and unos cuantos soldier's accoutrements. Then it was mi intención to go and entrar al servicio militar in Piedmont, porque ya estaba yo on the road to Alejandría de la Palla, I learned que el gran Duque of Alva was en camino a Flandes. Cambié mis planes, yo joined him, serví under him en las campañas he made, was present en las muertes of the Condes Heguemón and de Hornos, and was promoted a ser ensigned bajo un famoso capitán de Guadalajara, llamado Diego de Urbina. Tiempo después de mi arrival en Flandes llegaron noticias to the league that his Santidad del Papa Pío Quinto, of happy memory, había hecho con Venecia and España against el enemigo común, which were los Turks, who had just then with their fleet taken la famosa isla of Cyprus, que pertenecía a los Venecianos, una deplorable pérdida y también disastrous. Era conocido como fact que el Most Serene Don Juan de Austria, bro natural of our buen rey Don Felipe, venía como commander-in-chief de las fuerzas aliadas, and se escuchaban rumores of the vast preparaciones de guerra which were being made, all of which stirred mi corazón and filled me with un deseo to tomar parte en la campaña which was expected; y aunque I had reason de creer, and almost algunas promesas, that on the primera oportunidad that presented itself yo sería promovido to ser capitán, preferí to leave all and take myself, as I did, a Italia. And fue mi buena fortuna that Don Juan acababa de llegar a Génova, and iba to Nápoles to join the flota Veneciana, como hizo después en Mecina.

Puedo decir, in short, that I took part in that felicísima expedition, was promoted by this time a ser un capitán of infantría, cargo al que 
mi buena suerte rather than mis méritos raised me. Y ese día - $\tan$ afortunado for Christendom, porque then todas las naciones of the tierra fueron disabused del error bajo el cual they lay al imaginar a los Turks to be invincibles en el mar- ese día, I say, en el que el orgullo y arrogancia Ottomanos were broken, de los muchos that were there made felices (porque los Christians que murieron that day fueron más felices than those who quedaron vivos and victorious) yo solo was miserable; porque, en lugar de some corona naval that I might have expected si estos hubieran sido Roman times, en la noche that followed ese famoso día I found myself with cadenas on my feet and esposas on my hands.

Todo pasó de la following manera: El Uchalí, el rey of Algiers, un daring y successful corsario, habiendo atacado and taken the leading galera Maltesa (solo tres knights being todavía vivos in it, que estaban badly heridos), el jefe de la galera de Juan Andrea, abordo of which yo y mi compañía were placed, came to its relief, and haciendo as was bound to do en un caso así, salté on board de la galera enemiga, que, sheering off from that which que había atacado, previno que mis hombres me siguieran, and so I found myself solo in the midst of mis enemigos, who were en tales números that I was incapás to resist. En suma, fui tomado preso, covered with heridas. El Uchalí, como ustedes saben, sirs, hizo his escape with su escuadrón entero, and I was left un prisonero en su poder, the only tristeza being among so many joys, $\mathrm{y}$ yo el único captive among so many personas libres. Porque there were quince mil Christians, all at the remos en la flota Turkish, que regained their longed-for libertad that día.

Me llevaron a Constantinople, where el Gran Turk, Selim, nombró a my amo generalat-sea for having done his duty en la batalla and carried off the standard of the Orden de
Malta as evidence of su valor. El año siguiente, which was el de setenta y dos, I found myself en Navarino, rowing en la galera principal con las tres lanternas. Allí ví and observé cómo la opportunity was lost de capturar the whole flota Turkish en el puerto. Porque all the marines and janízaros that belonged a ella made sure that estaban a punto de ser atacados inside the very puerto, and had their ropas and pasamaques, or shoes, ready to huír at once por tierra without waiting to be embestidos, in tan gran miedo did they stand of our flota. Pero el Cielo ordenó otherwise, not for any falta or negligencia del general who commandó on our side, sino por sus pecados of Christendom, y porque it was Dios's will and plecer that nosotros siempre tuviéramos instruments de castigo contra quienes chastise us.

En efecto, El Uchalí took refugio en Modón, which es una isla near Navarino, and landing forces fortificaron la boca del puerto and esperaron silenciosamente until Don Juan retired. En esta expedición was taken la galera called the Prize, whose capitán era el hijo del famous corsario Barbarossa. Fue tomada por la galera Neapolitan principal llamada She-wolf, commandada por ese thunderbolt de guerra, ese father de sus hombres, ese successful e inconquistable capitán Don Álvaro de Bazán, Marquis de Santa Cruz. Y yo cannot help telling you lo que ocurrió at the capture of the Prize. El hijo de Barbarossa era tan cruel, and treated sus esclavos so badly, que, cuando los que were at the remos saw that the galera She-wolf was bearing down upon them and gaining upon them, todos al mismo tiempo dropped their remos and seized el capitán who stood on the stage at the end of the gangway gritándoles to row lustily; and passing him on from bench to bench, de propa a poa, they so bit him que antes que he had got much past the mast su alma had 
already gone to el infierno: tal era, as I said, la crueldad with which él los trataba, and el odio with which, in turn, they lo odiaban.

Regresamos a Constantinople, y el año siguiente, setenta y tres, it became known que Don Juan había tomado Tunis, taken el reino from los Turks, and placed Muley Hamet en posesión, putting un final to the esperanzas which Muley Hamida, el más cruel y valiente Moor del mundo, entertained of returning para reinar allá. El Grand Turk took la pérdida greatly to heart, and with the cunning que toda su raza posee, hizo la paz with los Venetians (que estaban más deseosos for it que él), and el año siguiente, setenta y cuatro, atacó la Goletta y el fuerte which Don John había dejado half built cerca de Tunis. Mientras ocurrían estos eventos, yo laboraba at the remos sin ninguna esperanza of freedom; at least yo no tenía ninguna esperanza of obtaining it by ransom, porque estaba firmemente resolved de no escribirle a mi padre, telling him de mis misfortunas.

Al final se perdió la Goletta, and el fuerte fell, before which there were setenta y cinco mil soldados Turkish regulares, así como más de cuatrocientos mil Moors y Arabs from podas partes de África, and in the train of all this great host such municiones and máquinas de guerra, and tantos prisoneros that con sus manos they might have cubrir la Goletta and el fuerte with handfuls de tierra. La primera en care fue la Goletta, hasta entonces reckoned impregnable, y cayó, not by any culpa of its defensores, que hicieron all that they could and should hacer, pero because la experiencia proved cuán fácil era hacer entrenchments de arena en el desierto, porque agua used to be found a dos palmos de profundidad, while the Turks no encontraron ninguna at two yards; and so by means of the cantidad de bolsas de arena they raised their works so high that they commanded las paredes del fuerte, sweeping them as if from a cavalier, so that nadie pudiera hacer a stand or maintain la defensa.

Fue la opinión común that our men no 73 hubieran shut themselves up en la Goletta, sino que hubieran esperado in the open at the landing-place, pero los que dicen eso lo hacen at random y con poco conocimiento of such matters; for if en la Goletta and en el fuerte there were barely siete mil soldiers, cómo hubiera podido un número tan pequeño, no importa qué tan resoluto, sally out and hold their own contra tantos like those del enemigo? Y cómo es posible to help losing a stronghold that is not relieved, above all cuando estaba rodeada por a host of determined enemigos en su propia tierra? Pero many thought, y yo también lo pensé, that it was un favor especial and mercy which el Cielo showed a España al permitirle la destrucción of that source and hiding place of mischief, that devourer, esponja, and moth of infinidad de dineros, fruitlessly wasted there to no other propósito salvo preserving la memoria of its captura por el invencible Charles Quinto; as if to make that eternal, as it is and will be, aquellas piedras were needed to sustentarla.

The fuerte also se perdió; pero los Turks fueron ganándolo inch by inch, for los soldiers que lo defendieron fought so valerosa and fuertemente that el número of the enemy matados en ventidós asaltos generales exceeded veinticinco mil. De los tres mil that remained vivos ni uno was taken unwounded, a clear and manifest prueba of their esfuerzo and resolución, and how sturdily ellos se defedieron and held their plazas. Un fuerte o torre pequeño which was in the middle of la laguna under the command of Don Juan Zanoguera, un gentleman Valenciano and a soldier famoso, se rindió upon terms. Tomaron prisonero a Don Pedro Puertocarrero, general of the Goletta, who had done todo 
en su poder to defend his fortaleza, and sintió tanto el haberla perdido that he died of grief en camino a Constantinople, where ellos were carrying him prisonero. They also took al general del fuerte, que se llamaba Gabrio Cervellón, un gentleman Milanés, a great ingeniero and a soldier very bravo. En estas dos fortalezas perished muchas personas notables, entre ellas Pagán de Oria, caballero of the Orden of St. John, un hombre of disposición generosa, as was shown by his suma liberalidad to his brother, el famoso John de Andrea de Oria; and lo que hizo his death the more lastimosa was that he was slain por unos Arabs to whom, viendo that the fuerte was now lost, he entrusted himself, and who offered to conducirlo in the hábito of a Moro de Tabarca, a small fuerte or estación en la costa held por el Genoese employed in the pesquería del coral. Estos Arabs le cortaron la cabeza and carried it to the general de las armadas Turkish, who proved on them la verdad de nuestro probervio Castilian, that "Que aunque la traición aplace, el traidor se aborrece;» porque they say que él ordenó those who brought him the present to be hanged por no haberlo traído alive.

Entre los Cristianos who were taken en el fuerte was one llamado Don Pedro de Aguilar, a native no sé de qué place en Andalusia, who had been assigned to the fuerte, un soldado of mucha repute and rara intelligence, quien tenía en particular a special gift por lo que llaman poetry. Lo digo because his suerte brought him to my galera and to my banco, and made him un esclavo to mi mismo master; and before nosotros partimos de ese puerto, este gentleman compuso dos sonnets by way of epitafios, uno sobre la Goletta and el otro sobre el fuerte. Y de verdad I may as well recitarlos, for los sé de memory, and I think they will causar gusto rather than disgusto.

En el instant que el captive mentionó the nombre de Don Pedro de Aguilar, Don Fernando miró at his companions y los tres smiled and cuando he came to hablar de los sonnets uno de ellos said:

«Before Vuestra Merced proceeds any further, le suplico to tell me what became of el tal Don Pedro de Aguilar, of whom usted ha hablado.»

«All I know,» repuso el captive, «es que después de haber estado in Constantinople dos años, he escaped en traje de Arnaut en compañía de un espía Greek pero whether he recobró his libertad o no I cannot decir, though creo que sí, because un año afterwards I saw al Griego en Constantinople, though I was unable to preguntarle what the result of su viaje was.»

«You are correcto,» returned el gentleman, «for that Don Pedro es my bro, y él está now in nuestra village, bueno, rico, married, and with tres hijos.»

«Gracias be to Dios,» dijo el captive, «for tantas mercedes he has shown him, porque to my mind there is no contento on earth que se compare con recovering lost libertad.»

«And más,» dijo el gentleman, «yo sé los sonnets que hizo my bro.»

«Repeat them, pues,» dijo el captive, «for you will recite mejor than I puedo.»

«With all my heart,» respondió el gentleman, «and that of la Goletta said thus:»

RECIBIDO EN JULIO DE $20 I 7$

ACEPTADO EN JULIO DE 2017 VERSIÓN FINAL DE OCTUBRE DE 2017 